Egyptian J. of Nutrition Vol. XXXIII No. 1 (2018)

\title{
Study the Effect of Gurmmar Aqueous Extract on Oxidative Stress of Diabetic Rats
}

\section{Amira HamdyAbd El -Aziz, Abd El-Rahman M. Attia and Maysa M. EI Mallah}

Nutrition and Food Science Dep., Faculty of Home Economics, Helwan University

\begin{abstract}
The present study was carried out to analyze the chemical composition of Gymnema sylvestre leaves powder, to identify its total phenolic compounds, also investigate the hypoglycemic effects of different doses of Gymnema sylvestre leaves aqueous extract (GAE) on oxidative stress of diabetic rats. A total of 30 male albino rats weighing $(150 \pm 5 \mathrm{~g})$ were used in this study. Rats were divided into two main group .The first main group (6 rats) fed on basal diet (BD) as a negative control group (NC). The second main group(24 rats) was injected intra-peritoneally with asingle dose of streptozitocin at a dose of $60 \mathrm{mg} / \mathrm{kg}$ body weight for induction of diabetes. The rats in this group divided into 4 subgroups ( $n=6$ each), subgroup (1) fed on basal diet, as a (positive control group). Subgroups (2, 3 and 4) fed on basal diet and treated orally with Gymnema water extract at (100 200 and $400 \mathrm{mg} / \mathrm{kg} \mathrm{b.wt/day)} \mathrm{respectively.} \mathrm{The} \mathrm{chemical} \mathrm{analysis} \mathrm{of}$ Gymnema sylvestre leaves powder showed that each 100 grams contained The highest concentration of total carbohydrate $(50.78 \%)$ followed by total fiber (14.93\%), total protein (12.8\%) and ash (9.9 $\%)$,while the lowest concentration was recorded for total fat (4.39
\end{abstract}




\section{Amira HamdyAbd El -Aziz, Abd El-Rahman M. Attia and.Maysa M. EI Mallah}

\%).The total phenolic compound (5073.9 ppm gymnenic acid equivalent), has been identified by HPLC.

Oral treating to diabetic rats with different doses of GAE at $(100,200$ and $400 \mathrm{mg} / \mathrm{Kg})$ improved the mean values of lipid profile, kidney functions, glucose, liver enzymes, malondialdhyde and glutathione peroxidase, as compared to the positive control group.GAE play an important role in decreasing the complications which were resulting from diabetes. In conclusion, Gymnema sylvestre extract has high effective antioxidant, hypoglycemic, hypolipidemic, hepatoprotective and nephroprotective effects in STZintoxicated rats. The hypoglycemic and antioxidant activity of GAE could be due to presence of many phenolic compounds detected in this study .

\section{Introduction}

Diabetes mellitus is a group of metabolic diseases characterized by hyperglycemia resulting from defects of insulin action, insulin secretion or both $(\boldsymbol{A D A}, \mathbf{2 0 1 1})$. Diabetes has taken place as one of the most important diseases worldwide, reaching epidemic proportions. Hyperglycemia in the course of diabetes usually leads to the development of micro vascular complications, and diabetic patients are more prone to accelerated atherosclerotic macro vascular disease. These complications account for premature mortality and most of the social and economical burden in the long term of diabetes (King et al ., 2010). Hyperglycemia increases oxidative stress, which contributes to the impairment of the main processes that fail during diabetes, insulin action and insulin 


\section{Egyptian J. of Nutrition Vol. XXXIII No. 1 (2018)}

secretion. In addition, antioxidant mechanisms are diminished in diabetic patients, which may further augment oxidative stress (Rains and Jain , 2011) and (Maritim et al ., 2003). Increasing evidence suggests that oxidative stress plays a role in the pathogenesis of diabetes mellitus and its complications (Brownlee, 2001).

The herbal medicines are becoming popular due to better results and safe use as compared to marketed drugs and more effective treatment of health problems (Smith and Reynard,2011) .The bioactive constituents found in many plant species are isolated for direct use as drugs, lead compounds, or pharmacological agents. These traditional approaches might offer a natural key to unlock diabetic complications (Babu et al.,2006). The chemical structures of a phytomolecule play a critical role in its antidiabetic activity. Several plant species being a major source of terpenoids, flavonoids, phenolics, coumarins, and other bioactive constituents have shown reduction in blood glucose levels (Jung et al., 2006) and (Ji et al.,2009). Various antidiabetic plant extracts like. Gymnema sylvestre (Asclepiadaceae )a vulnerable species is a slow growing, perennial, medicinal woody climber found in central and peninsular India. The leaves of this plant have been used in India for over 2000 years to treat madhumeha, or "honey urine." Chewing the leaves destroysthe ability to discriminate the "sweet" taste, giving it its common name, gurmar, or "sugar destroyer." (Kanetkar et al.,2007).

Plant constituents include two resins (one soluble in alcohol),gymnemic acids, saponins, stigmasterol,quercitol (Zarrelli et al.,2013), and the amino acid derivatives betaine, choline and trimethylamine (Fletcher et al.,2009). 


\section{Amira HamdyAbd El -Aziz, Abd El-Rahman M. Attia and.Maysa M. EI Mallah}

Gymnema sylvestre (GS) is considered to have potent antidiabetic properties. This plant is also used for controlling obesity, in the form of Gymnema tea (Rachh et al.,2010). Extracts of its leaves and roots are used in India and parts of Asiaas a natural treatment for diabetes, as they help lower and balance blood sugar levels (Xie et al., 2003) .

In addition, the plant possesses antimicrobial (Chodisetti et al.,2013) anti-hyphal (Vediyappan et al.,2013) antihypercholesterolemic (Bishayee and Malay,2000) and hepatoprotective activities (Rana and Avadhoot,2007). prevents dental caries caused by Streptococcus mutans ( Hiji ,20011), and is used in cosmetics (Valli and Rao ,2008). In addition, it is also used in the treatment of rheumatism, cough, ulcer, jaundice, dyspepsia, constipation, asthma, eye complaints, inflammations and snake bites.

Gymnema's antidiabetic activity appears to be due to a combination of mechanisms. Two animal studies on beryllium nitrateand streptozotocin-diabetic rats found Gymnema extracts doubled the number of insulin-secreting beta cells in the pancreas and returned blood sugars to almost normal (Paliwal et al.,2009) . Gymnema increases the activity of enzymes responsible for glucose uptake and utilization , and inhibits peripheral utilization of glucose by somatotrophin and corticotrophin (Nigur et al.,2008).Plant extracts have also been found to inhibit epinephrine-induced hyperglycemia. (Singh et al., 2008).

The present study aimed to analyze the Chemical composition of Gymnema sylvestre leaves powder, to indentify its total phenolic compounds, and to evaluate the effect of concurrent 


\section{Egyptian J. of Nutrition Vol. XXXIII No. 1 (2018)}

administration of Gymnema sylvestre leaves aqueous extract on oxidative stress Of Diabetic Rats.

\section{Materials and Methods}

\section{Plant}

The dried Gymnema sylvestre leaves were purchased as crude dried material from a local company for folk Medicinal Plants and Herbs, Cairo, Egypt. leaves were ground into a fine powder using a coffee mixer and stored in an air-tight contained, kept in a desiccators until analyzed and preparation.

\section{Rats}

Thirty mature male albino rats of Sprague Dawley strain weighing $(150 \pm 5 \mathrm{~g})$ and $10-12$ weeks old were purchased from Laboratory of Animal Colony Helwan Egypt. Rats were maintained under controlled hygienic conditions.

\section{Chemicals and biochemical kits}

Biochemical kits for determination of liver enzymes aspartate amino transferase (AST), alanine amino transferase ( $A L T$ ), alkaline phosphatase (ALP) and urea nitrogen, uric acid, creatinine, total cholesterol (TC), triglycerides (TG), high density lipoprotein (HDL), Malondialdehyde (MDA) and Glutathione peroxidase (GPx) were purchased from the gamma trade company for pharmaceutical and chemicals, Dokki, cairo ,Egypt. And chemicals were purchased from EL - Gomhorya company Cairo, city, Egypt. Streptozotocin (STZ) (Sigma-Aldrich, Germany) was purchased from sigma chemical company, St Louis, Missouri. USA. 


\section{Amira HamdyAbd El -Aziz, Abd El-Rahman M. Attia and.Maysa M. EI Mallah}

\section{Preparation of Gymnema sylvestretea:}

The dried leaves were milled using a coffee grinder into a fine powder. Gymnema sylvestre tea was prepared by using 25,50 and $100 \mathrm{~g}$ fine powder $/ 100 \mathrm{ml}$ distilled water and boiling for $5 \mathrm{~min}$ at $100{ }^{\circ} \mathrm{C}$ The solution was kept to stand for $10 \mathrm{~min}$ before being filtered, cooled to room temperature and adjusted to $100 \mathrm{ml}$ water before using (Renno et al., 2006) .

\section{Sensory evaluation:}

Tea was prepared freshly in boiled water at the concentration $10 \mathrm{~g} / 100 \mathrm{ml}$ and kept in thermo bottles, and was served warm during the different tests.Then sensory acceptance test expressed as taste, color, aroma, appearance and overall acceptability was evaluated by ten randomized volunteers (Ekissi et al., 2014).

\section{Chemical analyses of Gymnema sylvestre:}

Moisture, protein, fat, ash of Gymnema sylvestre (leaves) fine powder were determined separately according to the methods of the (A.O.A.C. 2000) ,while total carbohydrates were calculated by differences as following: Carbohydrate $\%=100-($ Moisture $\%+$ protein $\%+$ fat $\%+$ Ash $\%$ ).

\section{Determination of phenolic compounds:}

The ethanolic extract of total phenolic compounds were determined by HPLC according to (Singleton and Rossi ,1965).

\section{Preparation of Gymnema sylvestre Extracts :-}

One $\mathrm{kg}$ of dried, powdered leaves of Gymnema sylvestre leaves .were dissolved in 4 litres of distilled water and allowed to soak overnight. The suspension were centrifuged at $5000 \mathrm{rpm}$ for 20 


\section{Egyptian J. of Nutrition Vol. XXXIII No. 1 (2018)}

minutes and filtered through a Whatman No. 1 filter paper. The supernatant fluid was allowed to evaporate in sterile, glass petri dishes under tube light. When completely dry, the extract was collected by scraping and stored. Stock solution of aqueous extract was prepared by dissolving $500 \mathrm{mg}$ of the extract in $5 \mathrm{ml}$ of distilled water (Venugopaland Venugopal, 1994).

\section{IIIIPreparation of basal diet:}

Basal diet was prepared according to the method of (Reeves et al.,1993). It was consisted of $20 \%$ protein (casein), $10 \%$ sucrose , $4.7 \%$ fat (corn oil), $0.2 \%$ choline chloride, $1 \%$ vitamin mixture, $3.5 \%$ salt mixture and $5 \%$ fibers. The remainder was corn starch up to $100 \%$.

\section{Experimental design and grouping of rats:}

A total of 30 male albino rats weighing $(150 \pm 5 \mathrm{~g})$ fed one week on basal diet for adaptation.

After adaptation period the rats were divided into two main groups as follows:

The first main group (6 rats): fed on basal ( control negative group).

The second main group ( 24 rats): injected with streptozitocin to induce diabetes, animals was injected with a single dose of freshly prepared solution of streptozitocin monohydrate (dissolved in ice cold water) intra -peritoneally at a dose of $60 \mathrm{mg} / \mathrm{kg}$ body weight (Rao et al., 2001). Since streptozitocin is able to produce hypoglycemia as a result of massive pancreatic insulin release, rats were given $20 \%$ glucose solution, after 6 hours. The rats were kept for the next 24 hours on $5 \%$ glucose solution. $5 \%$ Glucose containing water bottles Iwere kept in the cages to prevent hypoglycemia (Gupta et al., 


\section{Amira HamdyAbd El -Aziz, Abd El-Rahman M. Attia and.Maysa M. EI Mallah}

2009). Control group rats were treated identically and served as diabetic control.

After 48 hours blood samples were drawn in order to ensure that hyperglycemia has been induced. The levels of blood glucose considered to be in normal ranges from $50-135 \mathrm{mg} / \mathrm{dl}$. Animals with fasting glucose levels $>120 \mathrm{mg} / \mathrm{dl}$ were considered as diabetic and chosen for experimental study (Pari and Maheswari, 1999).

\section{This groups divided into $\mathbf{4}$ subgroub as follows:}

\section{The experimental groups were as follows:-}

Subgroup(1): Diabetic rats fed on basal diet only, "Positive control".

Supgroup(2): Diabetic rats fed on basal diet and treated orally with Gymnema water extract in a dose of 100 $\mathrm{mg} / \mathrm{kg} \mathrm{b.wt/day.}$

Subgroup(3): Diabetic rats fed on basal diet and treated orally with Gymnema water extract in a dose of 200 $\mathrm{mg} / \mathrm{kg} \mathrm{b.wt/day.}$

Subgroup(4): Diabetic rats fed on basal diet and treated orally with Gymnema water extract in a dose of 400 $\mathrm{mg} / \mathrm{kg} \mathrm{b.wt/day.}$

At the end of the experimental period (4 weeks), rats were fasted over night before sacrificing. Blood samples collected from each rat and centrifuged at 3000 r.p.m. to separate the serum. Serum was carefully separated and transferred into dry clean Ebendorf tubes and kept frozen at $-20^{\circ} \mathrm{C}$ till analysis. 


\section{Egyptian J. of Nutrition Vol. XXXIII No. 1 (2018)}

Liver and kidney were removed by careful dissection and blotted free of adhering blood immediately, after sacrificing the rats. The organs were washed with cold saline and dried between two filter papers, then weighed (10\%) according to (Drury and Wallington, 1980).

\section{Biological evaluation:}

Biological evaluation of the different tested diets was carried by determination of feed intake (FI), body weight gain\% (BWG \%) and organs weight body weight\% according to (Chapman et al., 1959) using the following equation:

$$
\begin{aligned}
& \text { BWG\% = Final body weight }- \text { Initial body weight } / \text { Initial body } \\
& \text { weight } \times 100
\end{aligned}
$$

\section{Biochemical analyses}

Serum total cholesterol was determined according to (Allain et al., 1974), triglycerides (Fossati and Principe, 1982) and high density lipoprotein (Virella , 1977) were chemically measured. Low density lipoprotein (LDL) was calculated (Friedewald et al.,1972) . Serum glucose levels were determined according to the methods of (Trinder , 1969). Activities of serum liver enzymes aspartate amino transferase (AST), alanine amino transferase (ALT)and alkaline phosphatase (ALP) were chemically determined according to (Reitman and Frankel ,1975). Blood urea nitrogen was determined using Bio Meraux kits according to (Patton and Crouch ,1977), Serum uric acid (Haisman and Muller ,1977), Urea nitrogen in serum was determined calorimetrically according to (Henry et al., 1974).and creatinine concentrations were chemically determined (Bartels and Bohmer, 1971). Serum activity of GPX enzyme was determined according to the methods described by (Paglia and 


\section{Amira HamdyAbd El -Aziz, Abd El-Rahman M. Attia and.Maysa M. EI Mallah}

Valentaine ,1967), Serum MDA level as $\mu$ moles/dL. was determined as described by (Draper and Hadley, 1990).

\section{Statistical analysis}

The statistical analysis was carried out by using SPSS, PC statistical software (version 10.0; SPSS Inc, Chieago, USA).The results were expressed as mean $\pm S D$. Data were analyzed by one way analysis of variance (ANOVA). The differences between means were tested for significance using least significant difference (LSD) test at $(\mathrm{P}<0.05)$ (Steel and Torri, 1980).

\section{Results and Discussion}

Data presented in table (1) showed that drink tea prepared from dried Gymnema sylvestre leaves using different concentration (2.5, 5 or $10 \%$ ) of as preliminary study to evaluate its sensory characteristics. A significant difference in taste, color and overall acceptance were found between the different concentrations, while there was no significant different in aroma.Tea prepared using $2.5 \%$ concentration was more acceptable to all ten volunteers. These results are in agreement with (Sharmaet al .,2017) who showed that, Gymnema sylvestre liquid extract had a brownish green color, no specific odor and bitter in taste while dried extract was brown in color and also bitter in taste.

The result of chemical composition of dried Gymnema sylvestre leaves is recorded in table (2). The chemical analysis of dried Gymnema sylvestre leaves revealed that, The concentration of total carbohydrate $(50.78 \%)$ was the highest followed by total fiber 


\section{Egyptian J. of Nutrition Vol. XXXIII No. 1 (2018)}

$(14.93 \%)$, total protein $(12.8 \%)$, ash $(9.9 \%)$. While the lowest concentration was recorded for total fat (4.39\%).

These results are in agreement with (Sharma et al ., 2017) who found that, the proximate composition of Gymnema sylvestre powder like moisture ,crude fat, crude protein , crude fiber ,total ash and total carbohydrate contents were 7.38, 5.80, 10.94, 11.50, 9.49 and 54.89 per cent respectively.

Total phenolic compound in Gymnema sylvestre leaves extract is recorded in table (3).it is clear from table (2) that ,the concentration of total phenolic compound in Gymnema sylvestre leaves extract was 5073.9ppm(gymnenic acid equivalent). These results are in agreement with (Kritikar and Base , 2011) who showed that the major bioactive constituents of Gymnema sylvestre are a group of oleanane-type triterpenoid saponins known as gymnemic acids.

The gymnenic acid is made up of molecules whose atom arrangement is similar to that of glucose molecules. Those molecules fill the receptor locations on the taste buds for a period of one to two hours, thereby preventing the taste buds from being activated by any sugar molecules present in the food. Similarly the glucose-like molecules in the gymnemic acid fill the receptor locations in the absorptive external layers of the intestine thereby preventing the intestine from absorbing the sugar molecules (Sujin et al.,2009). Presence of gymnemic acid in leaves suppresses the transport of glucose from the intestine into the blood stream resulting lowering of blood sugar level,(Saneja et al,.2010). 


\section{Amira HamdyAbd El -Aziz, Abd El-Rahman M. Attia and.Maysa M. EI Mallah}

Table(4) showed that intraperitoneal injection of streptozotocin in a single dose $(60 \mathrm{mg} / \mathrm{kg}$ b.wt) to rats caused significant decreases $(P<0.05)$ in body weight gain, but caused an increase in feed intake, liver and kidney weight when compared to the negative control group. Oral administration of Gymnema sylvestre leaves extract (GAE) $(400 \mathrm{mg} / \mathrm{kg})$ to rats inflicted with oxidative stress caused significant $(P<0.05)$ increases in body weight gain, feed intake and as compared to the positive control group fed on(BD). All treated groups with oral administration of GAE at ( 100,200 and 400 $\mathrm{mg} / \mathrm{kg} / \mathrm{d}$ ) caused, non-significant changes in feed intake and BWG\% , as compared the positive control group. Oral administration of GAEat $(100,200$ and $400 \mathrm{mg} / \mathrm{kg} / \mathrm{d})$ caused significant decreases $(p<0.05)$, in liver and kidney weights/body weights $\%$, as compared to the positive control group.

These results are in agreement with (Pothuraju et al.,2013) different extracts (aqueous, methanol, ethanol and acetone) of Gymnema sylvestre have a role in the treatment of body weight gain and accumulation of lipids in epididymal fat tissue, liver and muscle. On the other hand(Reddy et al ., 2012) demonstrated that , feeding of aqueous extract of saponins rich in Gymnema sylvestre (100mg/ $\mathrm{kg} / \mathrm{d}$ ) for 8weeks reduced body weight gain and organ weight such as liver, kidney and heart.Also(Kang et al ., 2012) concluded that , an ethanol extract of Gymnema sylvestre $(100 \mathrm{mg} / \mathrm{kg} / \mathrm{d})$ fed for 4 weeks to STZ diabetic rats showed reduction in body weight, slightly increased liver weight and no change in kidney weight.

Data in table (5)showed that there were significant elevations in glucose levels of all the animals administered streptozotocin after three days as compared to normal control. On the other hand, there 


\section{Egyptian J. of Nutrition Vol. XXXIII No. 1 (2018)}

were significant increases in blood glucose levels in the untreated diabetic rats compared to the normal control group were continuous until the end of the study. Treated diabetic rats with different doses of gurmmar aqueous extract at (100,200 and $400 \mathrm{mg} / \mathrm{kg} \mathrm{b} \mathrm{wt})$ caused significant decrease in glucose level compared to the untreated diabetic rat $(+v e)$. The treated group with gurmmar aqueous extract at (400 mg/kg b.wt) normalized blood glucose level compared to control negative group.

These results are in agreement with (EI Shafey et al., 2012) and (Daisy et al.,2009) who showed that ,there are a significant reduction in plasma glucose level by $(20.20 \%)$ in diabetic rats treated with Gymnema sylvestre leaves extract at (18 mg/kg body weight) when compared with untreated diabetic rats. On the other hand(Sathya et al.,2008) reported that, oral administration with $(2 \mathrm{ml} / \mathrm{kg})$ of the water extract of Gymnema sylvestre leaf to both normal and diabetic rats caused a significant reduction in blood glucose level in diabetic rats.

Vaidya , (2011) demonstrated that ,Gymnemic acid has been found to interfere with the ability of the taste buds on the tongue to taste sweet and bitter. It is believed that by inhibiting the sweet taste sensation, it will limit their intake of sweet foods, and this activity may be partially responsible for its hypoglycemic effect .

Agarwal et al .,2000) explained the mechanisms by which gymnemic acids exert its hypoglycemic effects by several ways like, it increases secretion of insulin, promotes regeneration of islet cells, increases utilization of glucose: it is shown to increase the activities of enzymes responsible for utilization of glucose by insulin-dependent pathways, an increase in phosphorylates activity, decrease in 


\section{Amira HamdyAbd El -Aziz, Abd El-Rahman M. Attia and.Maysa M. EI Mallah}

gluconeogenic enzymes and sorbitol dehydrogenase, and it causes inhibition of glucose absorption from intestine by binding the glucose binding sites on transport receptors .

As shown in Table (6), the rats injected intraperitoneally with streptozotocin had significant increases in $(P<0.05)$ serum levels of total cholesterol (TC), triglycerides (TG) and low density lipoprotein (LDL) when compared to the negative control group. Oral administration of gurmmar aqueous extractat $(100,200$ and 400 $\mathrm{mg} / \mathrm{kg}$ ) to diabetic rats inflicted with oxidative stress resulted in significant decreases $(P<0.05)$ in the elevated serum TC, TG and LDL levels and an increase in serum HDL when compared to the positive control (+ve) group.

These results are in agreement with(Kim et al.,2016), (Li et al.,2015),(Aralelimath and Bhise , 2012), (Kang et al.,2012) and (Daisy et al., 2009)who concluded that, Oral administration with GS at $(100 \mathrm{mg} / \mathrm{kg}$ body weight daily) to STZ diabetic rats decreased TG ,TC,LDL-C levels and caused an increased in HDL-C levels in blood serum . Aralelimath and Bhise , (2012) explained the reasons for decreasing levels of triglyceride, cholesterol and LDL-cholesterol and increasing level of HDL-cholesterol might be due to an increase in insulin which caused an increased activity of lipoprotein lipase (Facilitated chylomicron transport through cell membranes) and a decreased activity of hormone-sensitive lipase (converted neutral fats into free fatty acids). Also (Mallet al.,2009) reported that ,G. sylvestre decreases total cholesterol, LDL-cholesterol, VLDLcholesterol and triglyceride levels in diabetic rats and that could be due to the presence of hypolipidemic agent such as sitosterol in the aqueous leaf extract. 


\section{Egyptian J. of Nutrition Vol. XXXIII No. 1 (2018)}

Data presented in table (6) showed that, intraperitoneal injection of streptozotocin (STZ) in a single dose at $60 \mathrm{mg} / \mathrm{kg} /$ day to rats caused hyperglycemia manifested by significant $(P<0.05)$ increases in blood urea nitrogen, uric acid, creatinine, when compared to normal control group (-ve) .Oral administration with different doses of of gurmmar aqueous extract (GAE)at 100,200 and $400 \mathrm{mg} / \mathrm{kg}$ b.wtto diabetic rats for 4 weeks induced significant $(P<$ 0.05 ) decreases in elevated blood urea nitrogen, uric acid, creatinine, when compared to positive control diabetic rats. Oral administration with gurmmar aqueous extract (GAE)at had the best effect in all kidney biomarker in serum near to the normal control group.

These results are in agreement with (Kishore and Singh,2017) who illustrated that, supplementation with homeopathic preparation of Gymnema sylvestre showed protective effect against Diabetic nephropathy (DN), since they exhibited beneficial effects on the blood glucose level, associated biomarkers of DN and advanced glycation end products (AGEs) in kidney, Moreover, biomarkers of diabetic nephropathy (uric acid, urea and creatinine level) were also improved after the administration of Gymnema sylvestre in diabetic animals. Also (Sathya et al.,2008) showed that, kidney biomarkers(Urea, uric acid and creatinine) levels were increased in untreated diabetic rats .But After oral administration treatment with water extract of Gymnema sylvestre leaf at $(2 \mathrm{ml} / \mathrm{kg}$.b.wt $)$ the levels of these biomarker were altered near to normal level .

As shown in Table (7), the rats injected intraperitoneally with streptozotocin (STZ) in a single dose at $60 \mathrm{mg} / \mathrm{kg} /$ day to rats had significant increases $(P<0.05)$ in serum levels of AST, ALT, ALP enzymes, when compared to the negative control group. Oral 


\section{Amira HamdyAbd El -Aziz, Abd El-Rahman M. Attia and.Maysa M. El Mallah}

administration of gurmmar aqueous extract at $(100,200$ and 400 $\mathrm{mg} / \mathrm{kg}$ ) to rats inflicted with oxidative stress resulted in significant decreases $(P<0.05)$ in the elevated serum AST, ALT and ALP when compared to the positive control (+ve) group. The mean value of liver enzymes decreased gradually with increasing the three dosages of (GAE).

These results are in agreement with (EI Shafeyet al.,2012) who concluded that, treated diabetic rats with Gymnema sylvestre leaves extract at (18 $\mathrm{mg} / \mathrm{kg}$ body weight) led to significant decrease in ALT and AST compared to untreated diabetic rats and (Pothurajuet al.,2013) who showed that different extracts (aqueous, methanol, ethanol and acetone) of Gymnema sylvestre play an important role in the treatment of liver diseases.

Data illustrated in table (8)showed that, rats subcutaneously injected with a single dose of STZ (positive control) had significant decrease in antioxidant enzymes activity glutathione peroxidase (GPx) in blood serum and enhanced the end product of lipid peroxidation (MDA) level in blood serum as compared with the negative control group .

Oral administration of gurmmar aqueous extractat $(100,200$ and $400 \mathrm{mg} / \mathrm{kg}$ ) group for four weeks after injection with a single dose of STZ showed significant increase in the (GPX) enzyme in blood serum, while the elevated (MDA) levels were found to be reduced back towards the normal level in the treated rats given the highest dose of (GAE). The level of antioxidant enzyme was significantly improved by administration of $(400 \mathrm{mg} / \mathrm{kg}$ b.wt) of gurmmar aqueous extract in STZ diabetic. 


\section{Egyptian J. of Nutrition Vol. XXXIII No. 1 (2018)}

These results are in agreement with (Ohmoriet al.,(2005) Discovered the antioxidant ability of Gymnema sylvestre when study the antioxidant activity of six teas against free radicals and LDL oxidation .

Vasi and Austin,(2009) concluded that, administration of Gymnema sylvestre extract to diabetic rats increased superoxide dismutase activity and decreased lipid peroxide by either directly scavenging the reactive oxygen species, due to the presence of various antioxidant compounds, or by increasing the synthesis of antioxidant molecules (albumin and uric acid) .

Kang et al., (2012) reported that, orall Gymnema sylvestre extract to diabetic rats decreased lipid peroxidation levels in serum, in liver and in kidney and decreased the activity of glutathione peroxidase in cytosolic liver and glutamate pyruvate transaminase in serum to normal levels.

Al-Rejaieet al.,(2012) concluded that , Gymnema sylvestre pretreatment at doses of 100,200 and $400 \mathrm{mg} / \mathrm{kg} / \mathrm{d}$ for 4 weeks decreased the malondialdehyde levels by increasing the dose.

Kang et al .,(2012) confirmed that,Oral feeding of ethanolic extract of Gymnema sylvestreshowed a reduction in lipid peroxidation product (e.g. malonaldehyde) in serum, in liver and in kidney in diabetic rats. Moreover, the extract increased glutathione content and also increased the activity of enzymes such as glutathione peroxidase (GSH-Px) , glutathione-S-transferase (GST) and catalase in rat liver. 


\section{Amira HamdyAbd El -Aziz, Abd El-Rahman M. Attia and.Maysa M. EI Mallah}

Table (1): Sensory Evaluation of tea drink prepared from dried Gymnema sylvestre leaves

\begin{tabular}{c|c|c|c|c}
\hline Samples & Taste & Color & Aroma & $\begin{array}{c}\text { overall } \\
\text { acceptance }\end{array}$ \\
\hline $2.5 \mathrm{gm} / 100 \mathrm{ml}$ & $13.800^{\mathrm{a}}$ & $24.100^{\mathrm{a}}$ & $25.00^{\mathrm{a}}$ & $24.400^{\mathrm{a}}$ \\
& \pm 2.347 & \pm 1.595 & \pm 0.00 & \pm 0.966 \\
\hline \multirow{2}{*}{$5 \mathrm{gm} / 100 \mathrm{ml}$} & $8.100^{\mathrm{c}}$ & $21.600^{\mathrm{b}}$ & $25.00^{\mathrm{a}}$ & $21.800^{\mathrm{b}}$ \\
& \pm 2.558 & \pm 1.837 & \pm 0.00 & \pm 1.549 \\
\hline \multirow{2}{*}{$10 \mathrm{gm} / 100 \mathrm{ml}$} & $3.900^{\mathrm{d}}$ & $16.100^{\mathrm{c}}$ & $25.00^{\mathrm{a}}$ & $15.700^{\mathrm{d}}$ \\
& \pm 2.378 & \pm 2.183 & \pm 0.00 & \pm 2.162 \\
\hline
\end{tabular}

All results are expressed as mean $\pm \mathrm{SD}$

Values in each column, which have different litters, are Significant different $(P<0.05)$

Table 2: chemical composition of dried Gymnema sylvestre leaves

\begin{tabular}{c|c}
\hline Parameters \% & Dry matter $(\mathrm{gm} / 100 \mathrm{~g})$ \\
\hline Ash content \% & 9.9 \\
\hline Total fat \% & 4.39 \\
\hline Total protein\% & 12.8 \\
\hline Total carbohydrate\% & 50.78 \\
\hline Total fiber\% & 14.93 \\
\hline Total moisture\% & 7.2 \\
\hline
\end{tabular}

Table 3: Concentrations of total polyphenolic compounds in Gymnema sylvestre leaves extract

\begin{tabular}{c|c}
\hline Parameters & Concentrations (ppm) \\
\hline Total phenols & $\begin{array}{c}5073.9 p p m \text { gymnenic acid } \\
\text { equivalent }\end{array}$ \\
\hline
\end{tabular}




\section{Egyptian J. of Nutrition Vol. XXXIII No. 1 (2018)}

Table (4): Effect of different doses of gurmmar aqueous extract on feed intake, body weight gain $\%$ and some organs weight/body weight $\%$ of diabetic rats

\begin{tabular}{|c|c|c|c|c|}
\hline$x^{x}$ & Feed Intake & BWG\% & $\begin{array}{l}\text { Organs } \\
\text { weigh \% }\end{array}$ & ight/body \\
\hline Groups & & & Liver & Kidney \\
\hline Control (2) "Hoalthy ratc" & $17.700^{\mathrm{a}}$ & $33.690^{a}$ & $2.483^{\mathrm{e}}$ & $0.479^{d}$ \\
\hline Control (-ve) Heaitny rats & \pm 1.122 & \pm 2.208 & \pm 0.095 & \pm 0.041 \\
\hline & $18.637^{a}$ & $17.208^{b}$ & $3.565^{\mathrm{a}}$ & $0.792^{\mathrm{a}}$ \\
\hline Control (+ve) "Diabetıc rats" & \pm 0.725 & \pm 1.186 & \pm 0.132 & \pm 0.064 \\
\hline $100 \mathrm{magA}$ - kgh w & $18.385^{a}$ & $16.352^{b}$ & $3.283^{b}$ & $0.703^{b}$ \\
\hline $100 \mathrm{mg}$ GAE/ kg D.W & \pm 1.032 & \pm 1.100 & \pm 0.106 & \pm 0.024 \\
\hline & $18.235^{\mathrm{a}}$ & $16.00^{b}$ & $3.036^{c}$ & $0.597^{c}$ \\
\hline GAE/ kg b.w & \pm 0.878 & \pm 0.768 & \pm 0.059 & \pm 0.020 \\
\hline DF/ & $17.976^{\mathrm{a}}$ & $15.360^{b}$ & $2.725^{\mathrm{d}}$ & $0.520^{d}$ \\
\hline $400 \mathrm{mg}$ GAE/ kg b.W & \pm 0.817 & \pm 0.642 & \pm 0.060 & \pm 0.029 \\
\hline
\end{tabular}

GAE: gurmmar aqueous extract

Mean values in each column with same letters are not significantly different.

LSD: Least significant differences $(P<0.05)$. 


\section{Amira HamdyAbd El -Aziz, Abd El-Rahman M. Attia and.Maysa M. EI Mallah}

Table (5): Effect of different doses of gurmmar aqueous extract on lipid profile of diabetic rats

\begin{tabular}{c|c|c|c|c}
\hline Groups & $\begin{array}{c}\mathrm{TC} \\
(\mathrm{mg} / \mathrm{dL})\end{array}$ & $\begin{array}{c}\mathrm{TG} \\
(\mathrm{mg} / \mathrm{dL})\end{array}$ & $\begin{array}{c}\mathrm{LDL} \\
(\mathrm{mg} / \mathrm{dL})\end{array}$ & $\begin{array}{c}\mathrm{HDL} \\
(\mathrm{mg} / \mathrm{dL})\end{array}$ \\
\hline Control (-ve) & $70.695^{\mathrm{d}}$ & $39.480^{\mathrm{c}}$ & $20.521^{\mathrm{e}}$ & $42.278^{\mathrm{a}}$ \\
"Healthy rats" & \pm 4.237 & \pm 3.594 & \pm 2.149 & \pm 2.370 \\
\hline Control (+ve) & $134.065^{\mathrm{a}}$ & $67.567^{\mathrm{a}}$ & $102.590^{\mathrm{a}}$ & $17.962^{\mathrm{e}}$ \\
"Diabetic rats" & \pm 7.882 & \pm 5.805 & \pm 6.014 & \pm 0.813 \\
\hline $100 \mathrm{mg} \mathrm{GAE} /$ & $124.907^{\mathrm{a}}$ & $62.206^{\mathrm{ab}}$ & $88.616^{\mathrm{b}}$ & $23.850^{\mathrm{d}}$ \\
kg b.w & \pm 8.213 & \pm 5.849 & \pm 5.779 & \pm 1.527 \\
\hline $200 \mathrm{mg} \mathrm{GAE} /$ & $108.500^{\mathrm{b}}$ & $54.819^{\mathrm{b}}$ & $68.431^{\mathrm{c}}$ & $29.105^{\mathrm{c}}$ \\
$\mathrm{kg} \mathrm{b.w}$ & \pm 7.328 & \pm 5.253 & \pm 4.359 & \pm 2.569 \\
\hline $400 \mathrm{mg} \mathrm{GAE} /$ & $92.879^{\mathrm{c}}$ & $45.359^{\mathrm{c}}$ & $51.314^{\mathrm{d}}$ & $34.754^{\mathrm{b}}$ \\
$\mathrm{kg} \mathrm{b.w}$ & \pm 5.550 & \pm 3.862 & \pm 5.281 & \pm 2.236 \\
\hline
\end{tabular}

GAE: gurmmar aqueous extrac

Mean values in each column with same letters are not significantly different. LSD: Least significant differences $(P<0.05)$. 


\section{Egyptian J. of Nutrition Vol. XXXIII No. 1 (2018)}

Table (6): Effect of different doses of gurmmar aqueous extract on kidney functions of diabetic rats.

\begin{tabular}{c|c|c|c}
\hline \multirow{2}{*}{ Groups } & Uric acid & Urea Nitrogen & Creatinine \\
\cline { 2 - 4 } Control (-ve) "Healthy rats" & $1.319^{\mathrm{e}}$ & $22.187^{\mathrm{e}}$ & $0.541^{\mathrm{e}}$ \\
& \pm 0.064 & \pm 1.705 & \pm 0.017 \\
\hline \multirow{2}{*}{ Control (+ve) "Diabetic rats" } & $2.510^{\mathrm{a}}$ & $59.918^{\mathrm{a}}$ & $1.364^{\mathrm{a}}$ \\
& \pm 0.082 & \pm 1.225 & \pm 0.044 \\
\hline \multirow{2}{*}{$100 \mathrm{mg} \mathrm{GAE} / \mathrm{kg} \mathrm{b.w}$} & $2.260^{\mathrm{b}}$ & $54.418^{\mathrm{b}}$ & $1.195^{\mathrm{b}}$ \\
& \pm 0.085 & \pm 1.459 & \pm 0.033 \\
\hline \multirow{2}{*}{$200 \mathrm{mg} \mathrm{GAE} / \mathrm{kg} \mathrm{b.w}$} & $2.095^{\mathrm{c}}$ & $44.806^{\mathrm{c}}$ & $0.953^{\mathrm{c}}$ \\
& \pm 0.115 & \pm 2.194 & \pm 0.057 \\
\hline \multirow{2}{*}{$400 \mathrm{mg} \mathrm{GAE} / \mathrm{kg} \mathrm{b.w}$} & $1.701^{\mathrm{a}}$ & $37.073^{\mathrm{a}}$ & $0.766^{\mathrm{a}}$ \\
& \pm 0.095 & \pm 1.867 & \pm 0.060 \\
\hline
\end{tabular}

GAE: gurmmar aqueous extract

Mean values in each column with same letters are not significantly different.

LSD: Least significant differences $(P<0.05)$.

Table (7): Effect of different doses of gurmmar aqueous extract on liver enzymes of diabetic rats

\begin{tabular}{c|c|c|c}
\hline \multirow{2}{*}{ Groups } & AST & ALT & ALP \\
\cline { 2 - 4 } Control (-ve) "Healthy rats" & $52.392^{\mathrm{a}}$ & $17.902^{\mathrm{e}}$ & $84.950^{\mathrm{e}}$ \\
& \pm 3.103 & \pm 1.873 & \pm 2.073 \\
\hline \multirow{2}{*}{ Control (+ve)"Diabetic rats" } & $93.160^{\mathrm{a}}$ & $55.484^{\mathrm{a}}$ & $156.940^{\mathrm{a}}$ \\
& \pm 4.992 & \pm 1.675 & \pm 8.798 \\
\hline \multirow{2}{*}{$100 \mathrm{mg}$ GAE/ kg b.w } & $87.801^{\mathrm{a}}$ & $50.517^{\mathrm{b}}$ & $145.082^{\mathrm{b}}$ \\
& \pm 3.936 & \pm 1.364 & \pm 7.271 \\
\hline \multirow{2}{*}{$200 \mathrm{mg} \mathrm{GAE} / \mathrm{kg}$ b.w } & $76.551^{\mathrm{b}}$ & $40.439^{\mathrm{c}}$ & $133.188^{\mathrm{c}}$ \\
& \pm 4.659 & \pm 1.181 & \pm 5.537 \\
\hline \multirow{2}{*}{$400 \mathrm{mg} \mathrm{GAE} / \mathrm{kg}$ b.w } & $66.991^{\mathrm{c}}$ & $32.914^{\mathrm{a}}$ & $120.382^{\mathrm{a}}$ \\
& \pm 4.076 & \pm 1.449 & \pm 4.588 \\
\hline
\end{tabular}

GAE: gurmmar aqueous extract

Mean values in each column with same letters are not significantly different.

LSD: Least significant differences $(P<0.05)$. 


\section{Amira HamdyAbd El -Aziz, Abd El-Rahman M. Attia and.Maysa M. EI Mallah}

Table (8): Effect of different doses of gurmmar aqueous extract on malonialdehyde and glutathione Peroxidase of diabetic rats

\begin{tabular}{c|c|c}
\hline Groups & $\begin{array}{c}\text { Malonialdehyde } \\
\text { MDA mmol/l }\end{array}$ & $\begin{array}{c}\text { Glutathione } \\
\text { Peroxidase } \\
(\mathrm{GPx})(\mathrm{ng} / \mathrm{ml})\end{array}$ \\
\hline Control (-ve) "Healthy rats" & $\begin{array}{c}8.00^{\mathrm{e}} \\
\pm 0.318\end{array}$ & $\begin{array}{c}0.538^{\mathrm{e}} \\
\pm 0.010\end{array}$ \\
\hline Control (+ve) "Diabetic rats" & $18.660^{\mathrm{a}}$ & $0.202^{\mathrm{a}}$ \\
& \pm 0.754 & \pm 0.007 \\
\hline \multirow{2}{*}{ 100 mg GAE/ kg b.w } & $16.832^{\mathrm{b}}$ & $0.286^{\mathrm{b}}$ \\
& $\pm 0.598^{\mathrm{a}}$ & \pm 0.022 \\
\hline \multirow{2}{*}{ 200 mg GAE/ kg b.w } & $14.221^{\mathrm{c}}$ & $0.413^{\mathrm{c}}$ \\
& \pm 0.859 & \pm 0.013 \\
\hline \multirow{2}{*}{$400 \mathrm{mg} \mathrm{GAE} / \mathrm{kg} \mathrm{b.w}$} & $12.128^{\mathrm{d}}$ & $0.468^{\mathrm{d}}$ \\
& \pm 0.592 & \pm 0.013 \\
\hline
\end{tabular}

GAE: gurmmar aqueous extract

Mean values in each column with same letters are not significantly different. LSD: Least significant differences $(P<0.05)$. 


\section{Egyptian J. of Nutrition Vol. XXXIII No. 1 (2018)}

\section{References}

A.A.C.C. (2000):

American Association of Cereal Chemistry Pub, By A American Association of Cereal Chemistry. Univ. of Fam.S St Paul. Minnesota.USA.

Agarwal,S.;Singh,S.;Verma,S.;Lakshmi,V.andSharmaA.(2000):

Chemistry and medicinal uses of Gymnema sylvestre (gurmar) Leaves: A Review. Indian Drugs ; 37: 354-360.

Allain, C.Z.; Poon, L.S. and Chan, C.S. (1974) :

Enzymatic determination of total cholesterol. Clin. N Chem., 20: $470-475$.

Al-Rejaie, S.S.; Abuohashish, H.M.; Ahmed, M.M.; Aleisa, A.M. and Alkhamees, O.(2012) :

Possible biochemical effects following inhibition of ethanolinduced gastric mucosa damage by Gymnema sylvestre in male Wistar albino rats. US National Library of Medicine National Institutes of Health.;50(12):1542-50.

American Diabetes Association(ADA) .(2011):

Diagnosis and classification of diabetes mellitus. DDiabetes care, 32(1), 627. 


\section{Amira HamdyAbd El -Aziz, Abd El-Rahman M. Attia and.Maysa M. EI Mallah}

Aralelimath,V.R. and Bhise , S.B. (2012):

Anti-diabetic effects of Gymnema sylvestre extract on streptozotocin induced diabetic rats and possible b-cell protective and regenerative evaluations. Dig. J.Nanomater. Biostruct.; 7 (1), 135-142.

Babu, P.; Suneetha, G. and Boddepalli, R.( 2006):

A databaseof 389 medicinal plants for diabetes. misinformation. 1(4):130-131.

Bartels, H.and Bohmer, M. (1971) :

Creatinine standard and measurement of serum Creatinine with picric acid. Clin. Chem.; Acta, $32: 81$.

Brownlee, M. (2001):

Biochemistry and molecular cell biology of diabetic complications. Nature, 414(6865), 813-820.

Chapman, D.G.;Castilla, R. and Compel, J.A. (1959):

Evaluation of protein in food.I.A. method for the determination of protein efficience ratio. Can J. Biochem physiol., 37:679686.

Chodisetti, B.; Rao, K. and Giri, A. (2013):

Phytochemical analysis of Gymnema sylvestre and evaluation of its antimicrobial activity. Nat. Prod. Res. 27,(7) 583-587. 


\section{Egyptian J. of Nutrition Vol. XXXIII No. 1 (2018)}

Daisy, P.; Eliza, J. and Farook, K. (2009):

A novel dihydroxy gymnemic triacetate isolated from Gymnema sylvestre possessing normoglycemic and hypolipidemic activity on STZ-induced diabeticrats. J. Ethnopharmacol. 126, 339-344.

Draper,H.andHadley,M.(1990):

Malondialde hydedertermination as index of lipid peroidatation. Methods Enzmol; 186: 421-431.

Drury, R.A. and Wallington, E.A. (1980):

carton's Histological Technique . Oxford University.9(5): 437444.

Ekissi ,A.C.; Konan,A.G.; Kouame,A.Y .;Bonfoh,B.and KatiCoulibaly,S.(2014):

Sensory evaluation of green tea from lippie multiflora moldenke leaves .European scientific Journal ,vol.10 NO.3,534-543.

EI Shafey,A.; Magda El-Ezabi ,M.; SeliemMoshira, E.; OudaHannen, H. and Ibrahim Doaa, S. (2012) :

Effect of Gymnema sylvestre R. Br. leaves extract on certain physiological parameters of diabetic rats.; 25: 135-141.

Fletcher, J.I.; Dingley, A.J. and Smith, R. (2009):

High-resolution solution structure of gurmarin, a sweettaste-suppressing plant polypeptide. Eur J Biochem. 1999; 264: 525-533. 


\section{Amira HamdyAbd El -Aziz, Abd El-Rahman M. Attia and.Maysa M. EI Mallah}

Fossati, P .and Principe, L. (1982) :

Enzymatic colorimetric method to determination triglycerides. Clin. Chem. 28, 2077.

Friedwald, W.T.; Leve R.I. and Fredrickson, D.S. (1972): Estunatuib of the concentration of low-density lipoprotein separated by three different method. Clin. Chem.; 18:499-502.

Gupta,V.; Bansal, A. Garg and A. Meena, (2009):

Pharmacopoeial standardization of Hibiscus rosa sinensis Linn. Int. J. Pharmaceut. Clin. Res., 1: 124-126.

Haisman, P .and Muller, B. (1977) :

Quantitative enzymatic colorimetric determination of uric acid in serum. Clin. Chem.; $26: 227$.

Henry, J. B.; Todd, M. K.; Sanford, L. U. and davidsohn, S.G. (1974):

Clinical Diagnosis and Measurement by Laboratory Methods. 16 thEd.W. B. Saunders and CO., Philadelphia, P . A PP.260.

Hiji, Y. (2011) :

Cariostatic Materials and Foods, and Method for Preventing Dental Caries. U.S. Patent 4912089A, 1.

Ji, H.F.; Li, X.J. and Zhang, H.Y.(2009):

Natural products and drug discovery: can thousands of years of ancient medical knowledge lead us to new and powerful drug combinations in the fight against cancer and dementia . EMBO Reports. 10(3):194-200. 


\section{Egyptian J. of Nutrition Vol. XXXIII No. 1 (2018)}

Kanetkar,P.; Singhal,R. and MadhusudanKamat . (2007):

Gymnema sylvestre: A Memoir,Us National Libarary of Medicine National Institutes of Health, doi: 10.3164/jcbn. 2007010 .

Kang , H.; Lee, S.; Choi, K.; Min, K. and Shibamoto ,T. (2012):

Hypoglycemic activity of Gymnema sylvestre extracts on oxidative stress and antioxidant status in diabetic rats. J Agric Food Chem.;60(10):2517-2524.

King, H.; Aubert, R. E. and Herman, W.H. (2010):

Global burden of diabetes, prevalence, numerical estimates, and projections. Diabetes Care, 21(9),1414-1431.

Kim,H.J.;Hong,S.H.;Chang,S.H.;Kim,S.;Lee,A.;Jang,Y.;Davaadam din,O.;Nam,K.; Kim,J.E. and Haing,M .(2016):

Effects of feeding a diet containing Gymnema sylvestre extract: Attenuating progression of obesity in C57BL/6J mice; 9(5): 437-444.

Kishore, L . AndSingh,R. (2017):

Preventive effect of gymnema sylvestre homeopathic preparation on streptozotocin - nicotinamide induced diabetic nephropathy in rats. Volume 17, Issue 3, pp 223-232| Cite as.

Kritikar , K. and Base, B . (2011) :

Indian Medicinal Plants, 4th ed., International Book Distributors, Dehradun, pp.1625. 


\section{Amira HamdyAbd El -Aziz, Abd El-Rahman M. Attia and.Maysa M. EI Mallah}

Li , Y.; Zheng, M.; Zhai, X.; Huang, Y.; Khalid, A.; Malik, A.; Shah, P.; Karim, S.; Azhar, S. and Hou, X. (2015):

Effect Of Gymnema Sylvestre, Citrullus Colocynthis And Artemisia Absinthium On Blood Glucose And Lipid Profile In Diabetic Human, Acta Pol Pharm.;72(5):981-5.

Mall, K.; Mishra, P. and Prakash, V. (2009):

Antidiabetic and hypolipidemic activity of Gymnema Sylvestre in alloxan inducedrats. Global J. Biotechnol. Biochem.; 4 (1), 37-42.

Maritim, A. C.; Sanders, R. A. and Watkins, J. B. (2003):

Diabetes, oxidative stress, and antioxidants: A review. Journal of Biochemical and Molecular Toxicology, 17(1), 24.

Nigur, G.L.; Samokhina, M.P.; Pisarev, V.B.; Spasov, A.A. and Bulanov, A.E.(2008):

Structural alterations in pancreatic islets in streptozotocininduced diabetic rats treated with of bioactive additive on the basis of Gymnema sylvestre. Morfologiia, 133, 60-64.

Ohmori, R.; Iwamoto, T.; Tago, M.; Takeo, T.; Unno, T.; Itakura, H. and Kondo, K. (2005):

Antioxidant activity of various teas against free radicals and LDL oxidation. Lipids 40 (8), 849-853.

Paglia, D.E. and Valentione, W.N. (1967):

Determination of glutathione peroxidease in tissue by uv method, J. Lab. Clin. Med. 70: 158-169. 


\section{Egyptian J. of Nutrition Vol. XXXIII No. 1 (2018)}

Paliwal, R.; Kathori, S. and Upadhyay, B. (2009):

Effect of Gurmar (Gymnema sylvestre) powder intervention on the blood glucose levels among diabetics. Ethno. Med. 3, 133-135.

Pari, L. and Maheswari ,U. (1999):

Hypoglycaemic effect of Musa L. in alloxan-induced diabetic rats.J Ethnopharmacol. ;68(1-3):321-5.

Patton, C.J. and Crouch, S. R. (1977):

Enzymatic color method of determination of urea in serum . Anal. Chem.; 49:464.

Pothuraju,R.;Sharma,R.;Chagalamarri,J.;Jangra,S.andKavadi,P.( 2013):

Asystematic review of Gymnema sylvestre in obesity and diabetes management, DOI: 10.1002/jsfa.6458.

Rachh, P.R.; Rachh, M.R.; Ghadiya,N.R.; Modi, D.C.; Modi, K.P.; Patel, N.M. and Rupareliya, M.T.(2010):

Antihyperlipidemic activity of Gymnema sylvestre R. Br. leaf extract on rats fed with high cholesterol diet. Int. J. Pharmacol. 2010, 6, 138-141.

Rains, J. L. and Jain, S. K. (2011):

Oxidative stress, insulin signaling, and diabetes. Free Radic Biol Med, 50(5), 567-575. 


\section{Amira HamdyAbd El -Aziz, Abd El-Rahman M. Attia and.Maysa M. EI Mallah}

Rana, .C. and Avadhoot, Y. (2007):

Experimental evaluation of hepatoprotective activity of Gymnema sylvestreand Curcuma zedoaria. Fitoterapia, 63, 60.

Rao, B.K. and C.H. Rao, (2001):

Hypoglycemic and antihyperglycemic activity of Syzygium alternifolium (Wt.) Walp. seed extracts in normal and diabetic rats. Phytomedicine, 8: 88-93.

Reddy, R.M.; Latha, P.B.; Vijaya, T.A. and Rao, D.S. (2012):

The saponin-rich fraction of a Gymnema sylvestre $\mathrm{R}$. Br. aqueous leaf extract reduces cafeteria and high fat dietinduced obesity. Z Naturforsch C. 67: 39-46.

Renno, W.M.; Saleh,F.; Klepcek.I.; AL-Khaledi,G.; Ismael,H. and Asfar,s. (2006):

Green tea pain modulating effect in sciatic Nerve chronic constriction injury rat model. Nutr Neurosci 9,41-47.

Reeves, P.G.; Nielsen, F.H. and Fahey, G.C. (1993):

AIN-93 purified Diet for laboratory Rodents: Final Report.

Reitman, S. and Frankel, S. (1975) :

A colorimetric method for the determination of serum glutamic oxalacetic and glutamic pyruvic transaminases. American Journal of Clinical Pathology, 28, 56-63. 


\section{Egyptian J. of Nutrition Vol. XXXIII No. 1 (2018)}

Saneja,A.; Sharma, C. and Pahwa, R . (2010):

Gymnema sylvestre (Gurmar): a review, Der Pharmacia Lettre ,Vol.2 No.1 pp.; 275-284 ref.49.

Sathya, S.; Kokilavani, R. and Gurusamy, K. (2008):

Hypoglycemic effect of Gymnema sylvestre (retz.,) R.Br leaf in normal and alloxan induced diabetic rats. Ancient Science of Life.;28(2):12-14.

Sharma,D.;Sawate,A.; Patil,B. and RB Kshirsagar,R. (2017):

Studies on physico chemical characteristics of Gymnema sylvestre (Leaf, powder and extract) , Journal of Pharmacognosy and Phytochemistry ; 6(5): 250-255.

Singh,K. ; Umar S.Ansari, A. and lqbal, M. (2008):

Gymnema sylvestre for diabetics. Journal of Herbs, Spices and Medicinal Plants. 14(1-2):88-106.

Singleton ,V.I. andRossi,J.A. (1965):

Colorimetry of total phenolics with phosphomolybdic phosphotungstic acid reagents .Am.J. Enolvitic 16:144-158.

Steel, R.G. andTorri, J.H. (1980) :

Principle and Procedures of Statistical Biometrical Approach. edn. Pbi. Mc Grew Hill Book Company ; New York ; U. S . A . 9(5): 437-444.

Sujin, M.; Subin, M.; Mahesh, R .and Mary, R. (2009): Antidiabetic effect of Gymnema sylvestre (asclepiadaceae) powder in the stomach of rats. Ethnobotanical leaflets ;12, 1158-1167. 


\section{Amira HamdyAbd El -Aziz, Abd El-Rahman M. Attia and.Maysa M. EI Mallah}

Smith, C.M. and Reynard, A.M. (2011):

Essentials of Pharmacology. Philadelphia, $\mathrm{Pa}$, USA: WB Saunders. 9(5): 437-444.

Trinder, P . (1969) :

Determination of blood glucose using 4-aminophenazone . Clin. Path., $22: 246$.

Vaidya,S. (2011):

Review On Gymnema: An Herbal Medicine For Diabetes Management, Dr.H.S.Gaur University, Sagar (M.P.),Pharmacia, Vol I, Issue 2.

Valli,K. N. and Rao, M.V. (2008):

In vitro micropropagation of Gymnema sylvestre A multipurpose medicinal plant. Plant Cell Tiss. Org. 61, 97105.

Vasi, S., Austin, A., (2009):

Effect of herbal hypoglycemic on oxidative stress and antioxidant status in diabetic rats. The Open Diabet. J. 2,4852.

Vediyappan, G.;Dumontet,V.; Pelissier, F.and d'Enfert,C.(2013):

Gymnemic acids inhibit hyphal growth and virulence in Candida albicans.PLoS One, 8, e74189. 


\section{Egyptian J. of Nutrition Vol. XXXIII No. 1 (2018)}

\section{Venugopal PV, Venugopal TV.(1994) :}

Disk diffusion susceptibility testing of dermatophytes with ally amines ,US National Library of Medicine National Institutes of Health; (33(10):730-2.

Virella, M. (1977) :

Cholesterol determination in high density lipoproteins separated by three different methods. Clin. Chem.; 23, 882.

Xie, A.; Wang, S. and Mehendale.V. (2003):

"Anti-diabetic effects of Gymnemay unnanense extract," Pharmacological Research, vol. 47, no. 4, pp. 323-329.

Zarrelli, A.; Della Greca, M.; Ladhari, A.; Haouala, R. and Previtera, L. (2013):

New triterpenes from Gymnema sylvestre. Helv.Chim.Acta 2013, 96, 1036-1045. 


\section{Amira HamdyAbd El -Aziz, Abd El-Rahman M. Attia and.Maysa M. EI Mallah}

دراسة تأثير المستخلص المائي للجورمار على الأجهاد التاكسدى فى الفئران المصابة بالسكر

أميرة حمدى عبد العزيز- عبد الرحمن محمد عطية ـ مايسة محمد الملاح قسم التظذية وعلوم الاطعمة ـ كلية الاقتصاد المنزلى - جامعة حوان

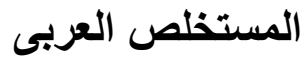

استهفت هذه الدراسة التحليل الكيميائى وتقدير المركبات الفينولية فى مسحوق أوراق الجورمار و معرفة تأثير المستخلص المائى للجورمار على الاجهاد التأكسدى فى ذكور الفئران

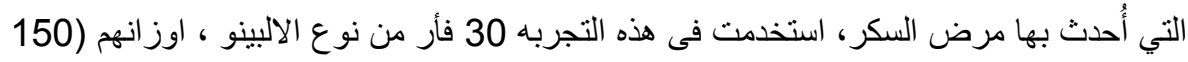

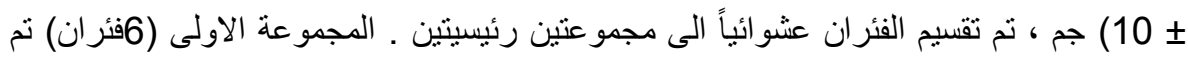
تغذيتها على غذاء اساسى واستخدمت كمجموعة ضابطة سالبة سليمة . المجموعة الرئيسية الثانية و عددها (24فأر) تم تقسيمهم الى اربعة مجموعات فرعية ( 6فئران لكل منهم ) وتم حقن الاربعة مجموعات من هذه الفئران بجرعة واحدة من محلول محضر حديثا من مادة الاستربتوزيتوسين (مذابة في ماء بارد مثلج) داخل الغشاء البريتوني بجرعة 60 مجم /كجم من وزن الجسم لاحداث

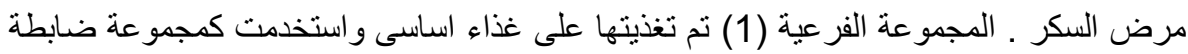

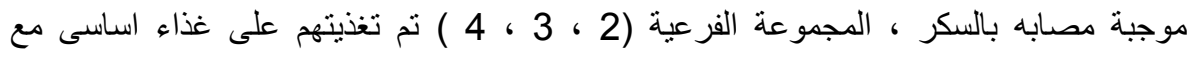
اعطاؤها عن طريق انبوب الفم منقوع مستخلص الجورمار بجرعات (100 ، 200 ، 400 ملجم

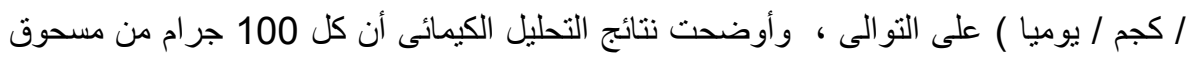
اوراق الجورمار احتوت على اعلى نسبة من الكربوهيدرات \% (50.78\%) ويليها الألياف

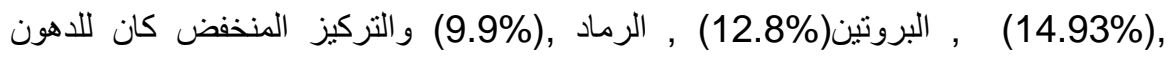
5073.9 ppm gymnenic acid) وكان التقدير الكلى للمركبات الفينولية (14.39\%),

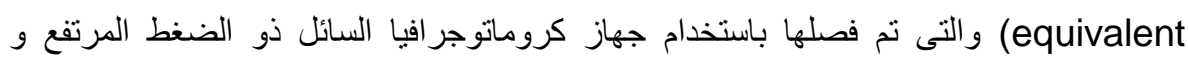
أشارت النتائج الى ان العلاج الفموى بجرعات مختلفة من مستخلص الجورمار (100 , 200 , 400 ملجم / كجم ) حدث تحسن ف بالدهون الكلية ، ومستوى جلوكوز الدم ، وظائف الكلى ، 


\section{Egyptian J. of Nutrition Vol. XXXIII No. 1 (2018)}

انزيمات الكبد ، ومالونديالدهيد , الجلوتاثيون بيروكسيداز فى الفئران المصابة بالسكر مقارنة بالمجموعة الضابطة المصابة , وأحدث اعطاء خلاصة اوراق الجورمار تأثثرات مضادة للأكسدة ومخفضة للسكر و لدهون الدم وواقية للكبد والكلى فى الفئران المصابة بالسكر وتقليل المشاكل

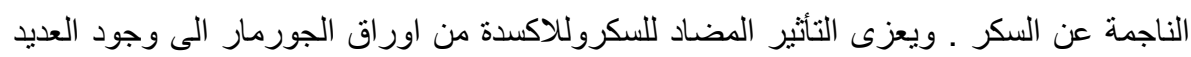

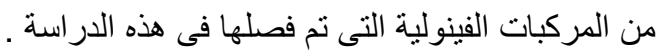

